\title{
Implications of Covid-19 Pandemic Lockdown on the Use of Social Media by University of Delhi Female Students Residing in International Students House for Women, India
}

\author{
Moruwawon Olabisi Iyabode \\ Department of Library and Information Science, Ekiti State University, Ado Ekiti, Nigeria
}

\begin{abstract}
Social media is a popular term known by all and sundry all over the world. It uses is a common experience among the old and young, especially among tertiary institution students. This study examined the implications of the use of social media during Covid-19 pandemic lockdown among the University of Delhi female students residing in the International Students House for Women (ISHW) New Delhi, India. The study was carried out using survey research method with online questionnaire as the instrument for data collection. The population of the study consists of about 105 University of Delhi female students residing in the International Students House for Women, New Delhi India. The data was presented and analyzed using tables. It was discovered from the analysis that majority of the students preferred the use of WhatsApp to other social media purposely to communicate with their friends and colleagues, for online teaching and learning, to carry out research, assignment and to acquire information about Covid-19 pandemic.
\end{abstract}

Keywords: Implications, COVID-19 Pandemic, Lockdown, Social Media, Students, Use

DOI: $10.7176 /$ RHSS/11-6-05

Publication date:March $31^{\text {st }} 2021$

\section{Introduction}

The present age is marked by social media. Both old and young are involved in the use of social media for one thing or the other. Information is majorly disseminated across the board through its use with the help of networking and interconnectivity. Social media has alleviated the barrier of distance and makes it possible to reach out to people living in different geographical locations. Social media is currently prevalent and widely used by all and sundry. It is one of the most crucial means of communication nowadays. It allows people to conveniently send, download, and share knowledge and information in form of text, pictures, video, and files. It also gives room for online social interaction.

Social media such as Blogs, Facebook, Twitter, Linkedln, Yahoo, Youtube, WhatsApp, Telegram, etc are commonly used among students for different purposes like academics, chatting, relationship improvement, motivation, team collaboration ${ }^{1}$. There is a proliferation of the use of social media among students, especially in tertiary institutions. The majority of the students use it as a means of interacting with one another outside the classroom settings for academics and social communication. The use of social media has changed the students' orientation and their performances ${ }^{2}$. Students from different countries can easily access the same information resources and as well share their knowledge. Some of the students are not depending on the knowledge and information acquired from their teachers only, but rather prefer going online to access and acquire more needed information for learning and research.

Social media is one of the tools responsible for the information explosion. For some years back, various sectors and the society at large are witnessing new trends in the means and mode of communication. There are the rapid and free conversations of knowledge, feelings, ideas, and information through social networking websites globally ${ }^{3}$. Students who are not having access to social media see themselves as inferior and low to those who have access to it. They believe that it is a norm to always be online to be able to hook with other colleagues and to display their abilities and ideas.

The $21^{\text {st }}$ century has witnessed unprecedented use of social media across the globe among old and young, literate, and semiliterate. Students of tertiary institutions are not left out. Social media is globally accepted as the easiest and cheapest means of communication among students, peers, friends, and relations. It's a recent way of exchanging information and gives the opportunity of creating personal information and engaging in communication with people online. Social media consists of a networking database environment and sharing devices such as audio and video media, Wikis, and Blogs ${ }^{4}$. Students are experiencing a proliferation of information, ideas, and innovation due to a rise in social media connections. Social media supports the global spread of information and easy learning. They also use social media for other activities besides learning.

${ }^{3}$ opined that social media raises students' self-esteem, assists them to flow along, and makes connections with other colleagues globally, encourages collaboration and teamwork. Notwithstanding, social networking websites can affect students' performances if not well controlled and managed. Some students spend excess time on social media such as Facebook, Internet, Twitter, YouTube, and so on for ungainful activities thereby 
affecting their academics. Students with high usage of social networking websites tend to perform lower than those who do not use it frequently. In the other hand, findings showed that social media websites transformed and increase relationships, socialization among people, strengthens technological advancement, information retrieval, and dissemination.

Students of tertiary institutions see social media websites as a tool to solve academic problems. Most of the times, they go online to carry out research on their assignment and search for more information on seemingly difficult academic activities or to gain more ideas and innovation. Studies show that the use of social media networking should be emboldened in teaching and learning for better performances and improvement. Higher institution students in the developed world viewed the challenges of using social media for learning as nothing and embraced its use because of the numerous benefits that accrue its uses ${ }^{1}$. Opinions, ideas, knowledge, information, experiences, and innovation are shared through social media networking among students and researchers. The right use of social media produces great privileges and innovations to students. The exchange of ideas is now an easy and common phenomenon among social media users. There is a free flow of information and communication online through the internet and other technologies ${ }^{2}$.

Social media network uses the product of web 2.0, internet, and other technology tools. It is a widely accepted platform by all and sundry mostly used for teaching and learning, research, chatting, send messages, consultancy, social interactions, and personal information such as photos, audio, and video. The $21^{\text {st }}$ century was greeted with internet-based information and communication. Students prefer accessing information online than consulting the library for a search of information. There has been a great revolution in the educator sector, research, teaching, and learning due to the multiplication of social media networks ${ }^{5}$. Social media is not only for entertainment and social interaction, but it is also educative and informative. It assists students from developing countries to access and expose to the same information and ideas as their counterparts in the developed world. It allows individual as well as group to express their feelings, and contribute intellectually and socially across the globe ${ }^{6}$.

Students' perception and that of the society at large has been induced by social media because of the way it is being used and the functions it performs. Some people, especially students have been adversely affected by the use of social media, this is unconnected with the way and manner they operate $\mathrm{it}^{10}$. The four-wall barrier to communication has been broken by social media in the present era. Technological progression is a good source to reach the unreached, educate the uneducated, and inform the uninformed. There is a possibility of a global internetworking connection within a jiffy through the application and use of social media with little or no stress. Tertiary institutions students in India are not left behind in the use of social media to tackle their educational and social problems. Social media network is becoming more rampant among them. A large percentage of the students cannot do without using social media platforms in a day either for academic purposes or social interactions ${ }^{7}$.

Covid-19 pandemic is a new infectious disease that started in Wuhan China in December 2019. Since then, there have been information and rumour flowing all around the globe through social media on the pandemic outbreak. Social media has been the major source of spreading and disseminating information to all categories of people about the COVID-19 pandemic even when there were lockdowns almost in all the countries of the world. Social media has played a vital role in this aspect. It is through the social network platforms that people are receiving information on what to do and how to do it to curb the spread of the pandemic. To contain the pandemic outbreak, all the sectors of the affected countries such as government parastatal, educational institutions at all levels, public and private companies were lockdown. People and governments started using social media network platforms such as the internet, WhatsApp, Twitter, zoom, and video conferencing to communicate and hold meetings. No physical and social gathering was allowed to reduce the fast spread of the pandemic. Covid-19 uncovers the benefits, functions of social media, and its dominance in spreading and disseminating information to the public ${ }^{8}$.

Group of people and individuals initiated some ideas, awareness, and debate for communication through social media due to rule of social distancing. Many people and organization also subscribed to some social network platform to receive and disseminate important information and messages to the masses/community. Some platforms (like Facebook, WhatsApp, YouTube) tried to restrain circulation of unwanted and fake information by taking some measures and guidelines to limit its spread. Information and instruction on how to manage and stop the circulation of the pandemic is being disclosed on social media network platforms. Various means of containing the disease such as wearing of nose masks, hand sanitizing, social distancing has taken their top most concern to disseminate to the public. Social media is an appropriate source of acquiring information on the covid-19 disease. Millions of people subscribe and use social media to keep themselves up-to-date on the issue of civid-19 pandemic. Despite the usefulness of social media in getting information on the pandemic, it has been noted that it is creating a sort of panic, and anxiety in people due to misinformation and exaggeration ${ }^{9}$.

India is one of the countries mostly affected by the covid-19 pandemic. Many people have contracted the virus and as a result, there are worries and anxieties everywhere. India government has instructed the social 
media networks to desist from propagating false and exaggerated information about the pandemic to reduce fear among the citizens ${ }^{9}$. Health sectors in some countries are collaborating with social media networks to start accounts on the platform as to disseminate accurate facts and information on covid-19 pandemic to the public.

\section{OBJECTIVES}

The main objectives of this study are to:

(i) Find out the preferred types of social media used by the students

(ii) Identify the purpose of using the social media during covid-19 pandemic lockdown

(iii) Evaluate the implication of social media use on their studies during the covid-19 pandemic lockdown

(iv) To ascertain the time spent daily on social media during covid-19 pandemic lockdown.

\section{METHODOLOGY}

An online survey was adopted by the researcher. The study was carried out with the aim of examining the implications of Covid-19 pandemic lockdown on the use of social media by some female students of University of Delhi, India. The population of the study comprises of $105(100 \%)$ postgraduate and undergraduate female students residing in the International Students' House for Women (ISHW) India, and same was used as the sample. The instrument used for data collection was a well-structured online questionnaire to draw out the opinions of the respondents. Four tables were designed in the questionnaire and administered to them online. Responses were collected using 5-point Likert-type scale ranging from strongly Agree, Agree, Neutral, Disagree, and Strongly Disagree. The questionnaire was derived keeping in mind the objectives and the research questions of the study.

\section{RESULTS}

Table 1: Items employed for objective 1: to find out the preferred types of social media used by the students

\begin{tabular}{|l|l|l|l|l|l|}
\hline Variables & $\begin{array}{l}\text { Strongly } \\
\text { Agree \% }\end{array}$ & Agree \% & Neutral \% & Disagree \% & $\begin{array}{l}\text { Strongly } \\
\text { Disagree \% }\end{array}$ \\
\hline Website & $19(30.2$ & $24(38.1)$ & $16(25.4)$ & $4(6.3)$ & $0(0)$ \\
\hline YouTube & $23(36.5)$ & $29(46.0)$ & $9(14.3)$ & $2(3.2)$ & $0(0)$ \\
\hline WhatsApp & $33(52.4)$ & $20(31.7)$ & $8(12.7)$ & $2(3.2)$ & $0(0)$ \\
\hline Telegram & $4(6.3)$ & $7(11.1)$ & $22(34.9)$ & $21(33.3)$ & $9(14.3)$ \\
\hline Blogs & $2(3.2)$ & $11(17.5)$ & $33(52.4)$ & $14(22.2)$ & $3(4.8)$ \\
\hline Facebook & $12(19.0)$ & $24(38.1)$ & $11(17.5)$ & $10(15.9)$ & $6(9.5)$ \\
\hline Instagram & $26(41.3)$ & $19(30.2)$ & $7(11.1)$ & $8(12.7)$ & $3(4.8)$ \\
\hline Twitter & $3(4.8)$ & $19(30.2)$ & $23(36.5)$ & $13(20.6)$ & $5(7.9)$ \\
\hline Zoom & $18(28.6)$ & $27(42.9)$ & $9(14.3)$ & $7(11.1)$ & $2(3.2)$ \\
\hline Skype & $3(4.8)$ & $19(30.2)$ & $25(39.7)$ & $7(11.1)$ & $9(14.3)$ \\
\hline Linkedln & $2(3.2)$ & $15(23.8)$ & $26(41.3)$ & $12(19.0)$ & $8(12.7)$ \\
\hline Snapchat & $15(23.8)$ & $12(19.0)$ & $13(20.6)$ & $14(22.2)$ & $9(14.3)$ \\
\hline Google Group & $19(30.2)$ & $24(38.1)$ & $13(20.6)$ & $5(7.9)$ & $1(3.2)$ \\
\hline
\end{tabular}

\section{Source: The researcher's survey 2020}

Table 1 shows the respondents preferred types of social media used during Covid-19 Pandemic lockdown. It is seen from the table that 33(52.4\%) of the respondents strongly agreed that the most preferred social media used during Covid-19 Pandemic lockdown is WhatsApp, followed by Instagram with 26(41.3\%). The third preferred social media is YouTube with $23(36.5 \%)$, while the least preferred social media are Blogs, and Linkedln with $3(4.8 \%)$ respectively. 
Table 2: Items employed for objective 2: to identify the purpose(s) of using the social media during Covid19 pandemic lockdown

\begin{tabular}{|l|l|l|l|l|l|}
\hline Variables & $\begin{array}{l}\text { Strongly } \\
\text { Agree \% }\end{array}$ & Agree \% & Neutral \% & Disagree \% & $\begin{array}{l}\text { Strongly } \\
\text { Disagree \% }\end{array}$ \\
\hline $\begin{array}{l}\text { I use social media to communicate and } \\
\text { chat with my friends during Covid-19 } \\
\text { pandemic lockdown }\end{array}$ & $41(65.1)$ & $13(20.6)$ & $8(12.7)$ & $0(0)$ & $1(1.6)$ \\
\hline $\begin{array}{l}\text { I use social media for watching } \\
\text { movies, downloading films and } \\
\text { pornography during Covid-19 } \\
\text { pandemic lockdown }\end{array}$ & $18(28.6)$ & $12(19.0)$ & $16(25.4)$ & $10(15.9)$ & $7(11.1)$ \\
\hline $\begin{array}{l}\text { I use social media for online classes } \\
\text { (teaching and Learning) during Covid- } \\
19 \text { lockdown }\end{array}$ & $38(60.3)$ & $19(30.2)$ & $3(4.8)$ & $3(4.8)$ & $0(0)$ \\
\hline $\begin{array}{l}\text { I use social media to discuss politics, } \\
\text { religion and national economy }\end{array}$ & $8(12.7)$ & $13(20.6)$ & $2031.7)$ & $16(25.4)$ & $6(9.5)$ \\
\hline $\begin{array}{l}\text { I use social media to carry out } \\
\text { assignment and research during Covid- } \\
\text { 19 lockdown }\end{array}$ & $7(11.1)$ & $18(28.6)$ & $8(12.7)$ & $4(6.3)$ & $26(41.3)$ \\
\hline $\begin{array}{l}\text { I use social media to get information } \\
\text { about Covid-19 pandemic during } \\
\text { lockdown }\end{array}$ & $22(34.9)$ & $27(42.9)$ & $8(12.7)$ & $5(7.9)$ & $1(1.6)$ \\
\hline I use social media for leisure & $22(34.9)$ & $21(33.3)$ & $15(23.8)$ & $4(6.3)$ & $1(1.6)$ \\
\hline
\end{tabular}

\section{Source: The researcher's survey 2020}

Table 2 represents the students' purpose(s) of using social media during Covid-19 pandemic lockdown. The highest percentage of the respondents $41(65.1 \%)$ strongly agreed that they used social media to communicate and chat with their friends during Covid-19 pandemic lockdown. 18(28.6\%) strongly agreed that they used social media for watching movies, downloading films, and pornography during this period. $38(60.3 \%)$ of them strongly agreed that social media was used for online teaching and learning classes during the pandemic lockdown. $18(28.6 \%)$ agreed that that they used social media to carry out research, and assignment, $27(42.9 \%)$ agreed using it to get information about Covid-19 pandemic lockdown and 22(34.9\%) strongly agreed using social media for leisure.

Table 3: Items employed for objective 3: to evaluate the implications of social media use on their studies during Covid-19 Pandemic lockdown.

\begin{tabular}{|l|l|l|l|l|l|}
\hline Variables & $\begin{array}{l}\text { Strongly } \\
\text { Agree \% }\end{array}$ & Agree \% & Neutral \% & Disagree \% & $\begin{array}{l}\text { Strongly } \\
\text { Disagree \% }\end{array}$ \\
\hline $\begin{array}{l}\text { Social media exposes me to valuable } \\
\text { information about Covid-19 Pandemic }\end{array}$ & $25(39.7)$ & $27(42.9)$ & $7(11.1)$ & $4(6.3)$ & $0(0)$ \\
\hline $\begin{array}{l}\text { Social media helps me to improve on } \\
\text { my academics }\end{array}$ & $19(30.2)$ & $15(23.8)$ & $23(36.5)$ & $4(6.3)$ & $0(0)$ \\
\hline $\begin{array}{l}\text { Social media enables me to meet my } \\
\text { teachers/lecturers to continue my } \\
\text { studies online }\end{array}$ & $8(12.7)$ & $22(34.9)$ & $12(19.0)$ & $2(3.2)$ & $19(30.2)$ \\
\hline $\begin{array}{l}\text { Social media reduces my reading and } \\
\text { studying time }\end{array}$ & $9(14.3)$ & $26(41.3)$ & $15(23.8)$ & $8(12.7)$ & $5(7.9)$ \\
\hline $\begin{array}{l}\text { I spend more time on social media } \\
\text { than studying my books }\end{array}$ & $14(22.2)$ & $21(33.3)$ & $17(27.0)$ & $10(15.9)$ & $1(1.6)$ \\
\hline $\begin{array}{l}\text { The use of social media motivates me } \\
\text { to study }\end{array}$ & $5(7.9)$ & $20(31.7)$ & $22(34.9)$ & $13(20.6)$ & $3(4.8)$ \\
\hline I use social media for cybercrime & $6(9.5)$ & $1(1.6)$ & $9(14.3)$ & $13(20.6)$ & $34(54.0)$ \\
\hline
\end{tabular}

\section{Source: The researcher's survey 2020}

Table 3 shows that $27(42.9 \%)$ of the respondents agreed that social media exposed them to valuable information about Covid-19 pandemic. 19(30.2\%) strongly agreed that social media helped them to improve on their academics, $22(34.9 \%)$ of them agreed that they were able to meet with their teachers/lecturers through social media during the pandemic lockdown. 26(41.3\%) agreed that social media reduces their reading and studying time during the lockdown, and 21(33.3\%) agreed that they spent more time on social media than studying their books. 
Table 4: Items employed for objective 4: to ascertain the time spent daily on social media during covid-19 pandemic lockdown.

\begin{tabular}{|l|l|l|l|l|l|}
\hline Variables & Strongly Agree \% & Agree\% & Neutral \% & Disagree \% & Strongly Disagree \% \\
\hline 30mins-1hour & $18(28.6)$ & $10(15.9)$ & $7(11.1)$ & $17(27.0)$ & $11(17.5)$ \\
\hline 2-3hours & $18(28.6)$ & $20(31.7)$ & $5(7.9)$ & $10(15.9)$ & $10(15.9)$ \\
\hline 4-5hours & $10(15.9)$ & $17(27.0)$ & $9(14.3)$ & $15(23.8)$ & $12(19.0)$ \\
\hline Above 5hours & $17(27.0)$ & $10(15.9)$ & $10(15.9)$ & $13(20.6)$ & $13(20.6)$ \\
\hline
\end{tabular}

\section{Source: The researcher's survey 2020}

Table 4 indicates the daily time duration the respondents spent on the social media during the Covid-19 pandemic lockdown. According to the data, 18(28.6\%) strongly agreed that they spent between 30 minutes to 1hour, and 2 to 3 hours daily respectively. 17(27.0\%) agreed spending 4 to 5hours and lastly, 17(27.0\%) strongly agreed spending 5 hours and above daily on social media.

\section{SUMMARY AND CONCLUSION}

The study investigated the implications of Covid-19 pandemic lockdown on the use of social media by University of Delhi female students residing in International Students' House for Women, India. Social media play a vital role in getting and disseminating information to others during the Covid-19 pandemic lockdown. Covid-19 pandemic has some implications on the students and the society at large. The findings of the study based on its objectives revealed that WhatsApp is the most preferred social media used by the respondents. Social media were purposefully used for communication, and chatting with friends and colleagues during the pandemic lockdown. Majority of the respondents also used the social media for online teaching and learning classes, carried out research and assignment and as well get information about Covid-19 pandemic and lastly used it for leisure. The study showed that some students spent more time on social media than studying their books during the lockdown. The time spent on the social media daily varies from 1 hour to 5 hours.

\section{REFERENCES}

Abdalellah, O.M., Basim, A.K., Abdul, N., \& Vigil, J.V. (2020). Emergency remote teaching during coronavirus pandemic: the current trend and future directive at middle east college oman. Innovative Infrastructure Solutions, 5(72). https//doi.org/10.1007/s41062-20-020-00326-7

Andy, L. (2019). What is technology? Open learn - open university. https://www.open.edu

Basila, G., \& Kvavadze, D. (2020). Transition to online education in schools during a SARS-COV-2 coronavirus (COVID-19) pandemic. Georgia Pedagogical Research, 5(4).

Encyclopedia Britannica, updated May 2020

David, A. (n.d). How technology can help improve education. https://www.techlearning.com

Edtech, T (2020). How countries are using edtech (including online learning, radio, television, texting) to support access to remote learning during the covid-19 pandemic. World Bank Edtech Team. March 2020June 2020

Fernando, R., Andreas, S. Jaime, S., \& Saku, T. (2020). Supporting the continuation of teaching and learning during the COVID-19 pandemic. Annotated resources for online learning. Global Education Innovation Initiative. www.oecd.org/education.

Fun, M.F., Ng, T.T., \& Robert, K.K. (2020). How to create engaging online learning amid COVID-19 pandemic: lesson from Singapore.

Janelle, C. (2019). K-12 news, lessons and shared resources by teachers, for teachers. Teach HUB.com

Jennifer, S., \& Diana, F. (2020). 10 strategies for online learning during a coronavirus outbreak. (ISTE) blog. Retrieved on June, 2020.

My gov.in. https://mygov.in. Retrieved on June, 2020

Mohd, S.A., Azfar, A.H., \& Harwati, H. (2019). Integrating web 2.0 technology in ESL classroom: a review on the benefits and barriers. Journal of counselling and educational technology (Electronic). http://journal.redwhitepress.com/index, 2(2), p01-08. Doi:https://doi.org/10.32698/0421.

Richa, C. (2020). Covid-19 pandemic: impact and strategies for education sector in India.

Shivangi, D. (2020). Online learning: a panacea in the time of COVID-19 crisis. Journal of Educational Technology Systems, 49(1), p5-22. DOI:10.1177004729520934018.

UN (2020). Policy brief: education during COVID-19 and beyond.

U.S department of education. Use of technology in teaching and learning. https://www.ed.gov $>$ oii-news $>$ use. Retrieved on June, 2020.

Yomi, K. (2020). Nigerian schools are being forced to rethink their digital limits and education models in a pandemic. Africa Reporters. 


\section{About the author}

Moruwawon, O. I. is an Assistant Lecturer at Ekiti State University, Ado Ekiti, Nigeria and currently a research scholar in the Department of Library and Information Science, University of Delhi, India. Her area of specialization includes ICT utilisation, and digital library. Her e-mail address is bisimoruwawon@gmail.com. 